\title{
SEMIOTIK FAUNA DALAM ACARA MANGUPA PADA PERKAWINAN ADAT TAPANULI SELATAN: KAJIAN EKOLINGUISTIK
}

\author{
Oleh: \\ Khatib Lubis \\ Email: khatib.lubis@um-tapsel.ac.id \\ Dosen Program Studi Pendidikan Bahasa dan Sastra Indonesia FKIP UMTS
}

\begin{abstract}
ABSTRAK
Penelitian Semiotik Fauna dalam Acara Mangupa Pada Perkawinan Adat Tapanuli Selatan: Kajian Ekolinguistik. Mangupa salah satu upacara adat Tapanuli, yang di adakan masyarakat, dengan menggunakan pira manuk na nihobolan (telur ayam), manuk (ayam), hambeng (kambing), horbo (kerbau), dll sebagai perangkat mangupa. Metode Penelitian analisis deskriptif makna Fauna secara ilmu tanda. Teknik pengumpulan data yang digunakan adalah kepustakaan dan wawancara langsung dengan masyaraat tapanuli selatan Berdasarkan hasil analisis peneliti adapun hasil penelitian ini adalah 1) dalam kehidupannya, khususnyadalam uapacara adat, masyarakat Tapanuli Selatan banyak menggunakan flora dan fauna sebagai alat untuk mengungkapkan pikiran dan perasaannya. 2) Makna keseluruhan dari lesikon fauna pada upacara adat Mangupa dalam perkawinan adat Tapanuli Selatan tersebut adalah berupa harapan dan doa demi kebahagiaan, kesejahteraan dan kesempurnaan hidup bagi orang yang diupah. 3) Masyarakat Tapanuli Selatan menyadari betapa pentingnya ekologi dalam mempertahankan kelangsungan hidup, ini dapat dibuktikan dengan pemakaian leksikon fauna dalam upacara adat Mangupa.
\end{abstract}

Kata kunci: Semiotik Fauna, Mangupa Perkawinan Adat Tapanuli Selatan, Kajian Ekolinguistik

\section{PENDAHULUAN}

Ekolinguitik adalah suatu disiplin ilmu yang mengkaji lingkungan dan bahasa. Ekolinguistik merupakan ilmu bahasa interdisipliner, menyanding ekologi dan linguistik (Meko, Aron 2008:1). Disiplin ilmu ini mengkaji hubungan timbal-balik antara bahasa dengan lingkungan manusia/sosial dan lingkungan alamiah. Istilah Ekolinguistik (ekologi bahasa) berhubungan dengan kata 'ekologi' yaitu ilmu yang mempelajari interaksi antara organisme dengan lingkungannya dan yang lainnya. Kajian Ekolinguistik memiliki parameter yaitu interrelationships (interelasibahasa dan lingkungan), environment (lingkungan ragawi dan sosial budaya) and diversity (keberagaman bahasa dan lingkungan) (Haugen dalam Fill dan Muhlhausler,2003:1). Jadi dapat dibedakan bahwa ranah kajian ekologi mencakup ketergantungan dalam suatu sistem, sementara dalam ekologi bahasa, konsep ekologi memadukan lingkungan, konservasi, 
interaksi, dan sistem dalam bahasa. Ekologi merupakan cabang ilmu yang mempelajari bagaimana makhluk hidup dapat mempertahankan kehidupannya dengan mengadakan hubungan antar makhluk hidup dan dengan benda tak hidup di tempat hidupnya atau lingkungannya. Ekologi bahasa merupakan interaksi antara bahasa yang sudah ada dan lingkungannya (masyarakat dan komunitas yang memakai bahasa tersebut atau sosiolinguistik). Sehingga parameter ekologis seperti keterhubungan, lingkungan lingkungan dan keberagamannya. Degradasi lingkungan diangkat menjadi kepedulian lingustik, yang berimplikasi pendekatan yang berbeda yang menjembatani studi bahasa dengan lingkungan dijadikan suatu kesatuan walaupun masih ada perbedaan pada ekolinguistik.

Ekolinguistik, ilmu pengetahuan antardisiplin ilmu, merupakan sebuah payung bagi semua penelitian tentang bahasa (dan bahasa-bahasa) yang dikaitkan sedemikian rupa dengan ekologi seperti yang dikatakan oleh Fill (1993:126) dalam Lindo \& Bundsgaard (eds.) (2000), mendefinisikan ekolinguistik sebagai berikut.

Ecolinguistics is an umbrella term for ' $[\ldots]$ all approaches in which the study of language (and languages) is in any way combined with ecology'.

Pembicaraan di antara para pakar bahasa tentang definisi ekologi bahasa, ekolinguistik atau linguistik hijau di dalam konteks khusus ini berhubungan dengan pembatasan terhadap obyek kajian ekolinguistik. Pakar-pakar di atas menekankan tujuan mereka kepada kesadaran meningkatkan kepedulian atas masalah-masalah yang direfleksikan secara ekologis yang ada hubungannya dengan gejala-gejala bahasa-bahasa dan ekologi dari perspektif yang lebih luas.

Sudut pandang mereka bahwa, teori ekologi dan bahasa saling berhubungan. Pandangan terhadap lingkungan yang dibentuk (dan membentuk) semua hubungan antar pesona bahasa yang sangat penting merupakan bagian dari masalah ekologi. Konsepsi/ pandangan bahasa dan ilmu bahasa juga menunjukkan bahwa bahasa (baik yang tertulis maupun lisan) dan lingkungan dianggap sebagai tujuan-tujuan kajian yang potensial.

Masyarakat Tapanuli Selatan merupakan masyarakat yang masih menjalankan upacara adat untuk berbagai keperluan, karena komunitas tersebut masih meyakini bahwa adat istiadat memiliki sistem yang teratur dalam pelaksanaan 
upacara adat perkawinan, misalnya, selalu digunakan perangkat adat yang diungkapkan menggunakan media bahasa tradisi (adat) pada umumnya menggunakan media bahasa. Bahasa adat merupakan alat komunikasi yang digunakan oleh komunitas pemakainya yang terwujud melalui leksikon-leksikon bahasa adat.

Dilihat dari leksikon bahasa sebagai leksikon adat, bahasa merupakan sistem isyarat "language is a system of codes" yang digunakan oleh kelompok sosial berdasarkan konvensi antara-anggota kelompok masyarakat dalam satu kesatuan adat. Leksikon bahasa merupakan sesuatu yang konvensional bagi komunitasnya. Isyaratisyarat yang digunakan harus merupakan kesepakatan bersama dari warga komunitas bahasa yang diejawantahkan dengan leksikon adat.

Komunitas penutur bahasa adat menggunakan tradisi lisan berwujud leksikon atau ungkapan yang sama untuk menyebut suatu keadaan atau ungkapan yang sama untuk menyebut sesuatu keadaan atau untuk penamaan sesuatu hal yang disebabkan oleh keperluan, keadaan di lingkungannya.

Bahasa isyarat (silent language, gesture) memiliki substansi utama yaitu gerak tubuh yang memberikan isyarat bermakna (non-vocalic, non-orthographic) namun dalam berkomunikasi, bahasa isyarat dilihat dari pengiriman isyarat (code-sender) dan penerima isyarat (code-receiver). Menurut Sapir (1921), Bahasa adalah murni kemanusiaan (purely humane) dan merupakan jalur non-instingtif (noninstinctive network) untuk mengkomunikasikan ide, emosi, kehendak, harapan dan cita-cita dengan memanfaatkan secara sengaja sistem yang dihasilkan oleh isyarat-isyarat bahasa dan kebahasaan. Sejalan dengan Sapir, Halliday (1978) menyatakan bahwa bahasa merupakan semiotik sosial. Semiotik sosial menurut Sinar (2003) adalah sistem makna yang direalisasikan melalui sistem linguistik, yang terwujud dengan penggunakan dengan melalui leksikon pada upacara adat berbentuk tradisi lisan. Tradisi lisan pada upacara adat di Tapanuli Selatan digunakan untuk berbagai hal yang menyangkut hidup dan kehidupan komunitas pemiliknya. Tradisi lisan yang digunakan pada upacara adat merupakan kearifan lokal (local wisdom) karena, berfungsi mengatur sistem nilai, pengetahuan tradisional (local knowledge), hukum, pengobatan, sistem kepercayaan dan religi, begitu pula pada 
upacara adat perkawinan. Lingkungan bahasa dalam Ekolinguistik meliputi lingkungan ragawi dan sosial (Sapir dalam Fill dan Muhlhausler, 2001:14). Lingkungan ragawi menyangkut geografi yang terdiri atas fisik: topografi suatu negara (pesisir, lembah, daratan, dataran tinggi, gunung), iklim, dan intensitas curah hujan, dasar ekonomis kehidupan manusia yang terdiri dari fauna, flora, dan sumber-sumber mineral; sedangkan lingkungan sosial terdiri atas berbagai kekuatan masyarakat yang membentuk pikiran dan kehidupan setiap individu di antaranya: agama, etika, bentuk organisasi politik, dan seni.

Sehubungan dengan ruang kaji Ekolinguistik Haugen (1970), lihat Mbete (2009:11-12), menyatakan bahwa Ekolinguistik memiliki kaitan dengan sepuluh ruang kaji, yaitu: (1) linguistik historis komparatif; (2) linguistik demografi; (3) sosiolinguistik; (4) dialinguistik; (5) dialektologi; (6) filologi; (7) linguistik preskriptif; (8) glotopolitik; etnolinguistik, linguistik antropologi ataupun linguistik kultural (cultural linguistics); dan (10) tipologi bahasa-bahasa di suatu lingkungan.

Indonesia adalah negara yang terdiri dari berbagai suku. Tiap suku mempunyai tradisi dan adat istiadat yang merupakan kekayaan bangsa. Namun seiring dengan berjalannya waktu dan arus modernisasi, terjadi perubahan baik di lingkungan lingkungan ragawi dan sosial. Tradisi dan adat istiadat serta bahasa sebagai ciri utama keberadaan suku bangsa Indonesia perlahan mengalami erosi. Diperlukan kajian yang mendalam yang mengkaitkan budaya dan lingkungan dengan tujuan penyelamatan dan pelestarian segala kekayaan budaya dan lingkungan. Nampaknya ruang kaji Ekolinguistik yang bisa mengakomodir telaah lanjut mengenai budaya dan lingkungan adalah telaah linguistik kultural. Tautan kedua kajian linguistik makro tersebut diharapkan dapat memberikan sumbangan pada upaya revitalisasi budaya dan lingkungan termasuk bahasa sebagai peranti interaksi masyarakat.

Dalam kehidupan sehari-hari, masyarakat Tapanuli Selatan selalu dilandasi oleh kebudayaan yang telah dimiliki sejak beratus tahun yang lalu. Hal ini terlihat dalam upacara adat, baik adat kelahiran, adat perkawinan, adat kematian dan sebagainya. Upacara-upacara adat yang terdapat dalam masyarakat Tapanuli Selatan merupakan ungkapan dari perilaku, citacita, kepribadian dan pegangan hidup masyarakatnya dan hal 
ini dimaknai dan dijembatani melalui perlengkapan dan tata cara pelaksanaannya.

Dalam pelaksanaan upacara-upacara adat sebagai cermin kehidupan bermasyarakat khususnya dalam interaksi budaya dan adat istiadat tersebut masyarakat Tapanuli Selatan banyak menggunakan kosakata (leksikon) flora dan fauna sebagai alat untuk mengungkapkan dan merepresentasikan pikiran dan perasaannya. Salah satu contoh upacara misalnya menyambut kelahiran bayi, dibuatlah suatu upacara adat yaitu bangun-bangun $n i$ daganak sorang (membangun semangat) dengan tujuan mengupah upah ibu yang melahirkan dan anak yang baru lahir agar mendapat keselamatan dan keberkahan hidup dari Yang Maha Kuasa.

Begitu juga halnya dalam pantun yang disampaikan pada upacara-upacara adat misalnya dalam acara Mangupa pada perkawinan adat, penggunaan terminologi flora dan fauna tidak lepas dari perhatian masyarakat Tapanuli Selatan. Misalnya:

Ma dison piramanuk na dihobolan

Dohot ihan na pitu sunge

Horas mada tondi dohot badan

Pitu sundut tong magabe

Horbo na marbara Manuk na marlobu

\section{Martamba ha ma mora}

\section{Markoum martamba rosu}

Pemakaian leksikon fauna pada pantun di atas merupakan bukti interaksi masyarakat Tapanuli Selatan dengan lingkungannya dengan cara mengabadikan ekologi dan lingkungan sekitarnya ke dalam bahasa yang bermuatan ekologi. Salah satu contoh dari upacara yang masih dapat dilihat sampai sekarang adalah Mangupa. Mangupa adalah salah satu kebiasaan adat dan tidak pernah ditinggalkan dalam upacara adat Tapanuli Selatan. Mangupa dilakukan pada adat perkawinan, kelahiran, upah-upah atau memberi semangat bagi orang yang luput dari marabahaya, mendapat rezeki atau sebagai rasa syukur.

Bahan-bahan yang dipakai untuk mangupa berupa flora yang terdapat dilingkungan sekitar. Bahan-bahan tersebut masing-masing mempunyai makna yang merupakan saksi keberlangsungan kehidupan sosial dan budaya masyarakatTapanuli Selatan yang berlangsung secara turun temurun. Dengan kata lain, bahan-bahan yang dipakai tersebut merupakan tanda yang merujuk pada perilaku, cita-cita, kepribadian dan pegangan hidup masyarakatTapanuli Selatan. 
Bertolak dari anggapan bahwa sebagai pengguna bahasa, masyarakat dikelilingi

oleh tanda, diatur oleh tanda, ditentukan oleh tanda, bahkan dipengaruhi oleh tanda. Tanda-tanda itu mengandung makna (Pateda, 2001:25), dan Kenyataannya bahwa bahasa sangat berkaitan erat dengan lingkungannya, serta fakta bahwa kajian Ekolinguistik menelaah interaksi bahasa dengan ekologinya maka dapat disimpulkan bahwa setiap interaksi bahasa yang terjadi dalam kelompok masyarakat pasti berhubungan dengan lingkungannya di mana terdapat kesepakatan atas pemakaian sistem tanda tertentu sebagai representasi pikiran, perasaan, ide-ide, atau harapannya.

Makalah ini membahas tentang jenisjenis fauna yang digunakan dalam Mangupa sebagai tanda budaya masyarakat Tapanuli Selatan dan makna yang dirujuk pada masing-masing fauna tersebut. Lingkungan bahasa yang yang menjadi fokus dalam makalah ini mencakup lingkungan ragawi yaitu fauna, dan lingkungan sosial yaitu etika sebagai kekuatan masyarakat yang membentuk pikiran dan kehidupan setiap individu.

Ruang kaji Ekolinguistik pada makalah ini adalah linguistik kultural (Cultural Linguistics).Pengkajian makna merujuk pada teori semiotik dengan yang dikemukakan oleh Halliday (1978) yang memandang bahasa sebagai semiotik sosial dalam memberikan interpretasi terhadap bahasa dan makna. Konsep tanda yang dijadikan acuan dalam makalah ini adalah trilogi tanda Peirce yaitu ikon, indeks, dan simbol. Dalam hal ini adalah telaah atas simbol sebagai sesuatu yang digunakan untuk menunjuk sesuatu yang lainnya berdasarkan kesepakatan (konvensi).

\section{PEMBAHASAN}

\section{SEMIOTIK}

Secara etimologis, semiotik atau semiotika berasal dari kata Yunani “Semeion” yang berarti “Tanda”. Tanda itu sendiri diartikan sebagai sesuatu yang dapat mewakili sesuatu yang lain. Contohnya : asap bertanda adanya api. Semiotik adalah ilmu yang mengkaji tanda dalam kehidupan manusia, yang mana tanda-tanda tersebut haruslah dimaknakan (Hoed, 2007:3). Secara Terminologis, semiotik dapat diartikan sebagai ilmu yang memepelajari sederetan peristiwa yang terjadi di seluruh dunia sebagai tanda. Pengertian yang paling singkat yang dikemukakan oleh Preminger (2001:89). Semiotik adalah ilmu tentang tanda-tanda. Ilmu ini menganggap bahwa 
kejadian sosial di masyarakat dan kebudayaannya merupakan tanda-tanda.

Secara terminologis, semiotik adalah cabang ilmu yang berurusan dengan dengan pengkajian tanda dan segala sesuatu yang berhubungan dengan tanda, seperti sistem tanda dan proses yang berlaku bagi tanda (van Zoest, 1993:1). Semiotik merupakan ilmu yang mempelajari sederetan luas obyek-obyek, peristiwa-peristiwa, seluruh kebudayaan sebagai tanda. Ahli sastra Teew (1984:6) mendefinisikan semiotik adalah tanda sebagai tindak komunikasi dan kemudian disempurnakannya menjadi model sastra yang mempertanggungjawabkan semua faktor dan aspek hakiki untuk pemahaman gejala susastra sebagai alat komunikasi yang khas di dalam masyarakat mana pun. Semiotik merupakan cabang ilmu yang relatif masih baru. Penggunaan tanda dan segala sesuatu yang berhubungan dengannya dipelajari secara lebih sistematis pada

abad kedua puluh.

Analisis semiotik modern diwarnai dengan dua nama yaitu seorang linguis yang berasal dari Swiss bernama Ferdinand de Saussure (1857 - 1913) dan seorang filsuf Amerika yang bernama Charles Sanders Peirce (1839 -1914). Peirce menyebut model sistem analisisnya dengan semiotik dan istilah tersebut telah menjadi istilah yang dominan digunakan untuk ilmu tentang tanda. Semiologi de Saussure berbeda dengan semiotik Peirce dalam beberapa hal, tetapi keduanya berfokus pada tanda.

Dalam bukunya yang berjudul $A$ Course in General Linguistics (1913) de Saussure membayangkan suatu ilmu yang mempelajari tanda-tanda dalam masyarakat. Ia juga menjelaskan konsep-konsep yang dikenal dengan dikotomi linguistik. Salah satu

dikotomi itu adalah signifier dan signified (penanda dan petanda). Ia menulis "the linguistics sign unites not a thing and a name,but a concept and a sound image a sign". Kombinasi antara konsep dan citra bunyi adalah tanda (sign). Jadi de Saussure membagi tanda menjadi dua yaitu komponen, signifier (atau citra bunyi) dan signified (atau konsep) dan dikatakannya bahwa hubungan antara keduanya adalah arbitrer.

Semiologi didasarkan pada anggapan bahwa selama perbuatan dan tingkah laku manusia membawa makna atau selama berfungsi sebagai tanda, harus ada di belakang sistem pembedaan dan konvensi yang memungkinkan makna itu. Di mana ada tanda, di 
sana ada sistem (de Saussure, 1988:26). Sekalipun hanyalah merupakan salah satu cabangnya, namun linguistik dapat berperan sebagai model untuk semiologi. Penyebabnya terletak pada ciri arbiter dan konvensional yang dimiliki tanda bahasa. Tanda-tanda bukan bahasa pun dapat dipandang sebagai fenomena arbiter dan konvensional seperti mode, upacara, kepercayaan dan lain-lainya.

Dalam perkembangan terakhir kajian mengenai tanda dalam masyarakat didominasi karya filsuf Amerika. Charles Sanders Peirce (1839 - 1914). Kajian Peirce jauh lebih terperinci daripada tulisan de Saussure yang lebih programatis. Oleh karena itu istilah semiotika lebih lazim dalam dunia Anglo-Sakson, dan istilah semiologi lebih dikenal di Eropa Kontinental.

Charles Sanders Peirce adalah seorang filsuf Amerika yang paling orisinal dan multidimensioanl. Peirce selain seorang filsuf juga seorang ahli logika dan Peirce memahami bagaimana manusia itu bernalar. Peirce akhirnya sampai pada keyakinan bahwa manusia berpikir dalam tanda. Maka diciptakannyalah ilmu tanda yang ia sebut semiotik. Semiotika baginya sinonim dengan logika. Secara harafiah ia mengatakan
“Kita hanya berpikir dalam tanda”. Di samping itu ia juga melihat tanda sebagai unsur

dalam komunikasi.

Semakin lama ia semakin yakin bahwa segala sesuatu adalah tanda artinya setidaknya sesuai cara eksistensi dari apa yang mungkin (van Zoest, 1993:10). Dalam analisis semiotiknya Peirce membagi tanda berdasarkan sifat ground menjadi tiga kelompok yakni qualisigns, sinsigns dan legisigns. Qualisigns adalah tanda-tanda yang

merupakan tanda berdasarkan suatu sifat. Contoh, sifat merah merupakan qualisgins karena merupakan tanda pada bidang yang mungkin. Sinsigns adalah tanda yang merupakan tanda atas dasar tampilnya dalam kenyataan. Semua pernyataan individual yang tidak dilembagakan merupakan sinsigns. Sebuah jeritan bisa berarti kesakitan, keheranan atau kegembiraan. Legisigns adalah tanda-tanda yang merupakan tanda atas

dasar suatu peraturan yang berlaku umum, sebuah konvensi, sebuah kode. Tanda lalu lintas adalah sebuah legisigns. Begitu juga dengan mengangguk, mengerutkan alis, berjabat tangan dan sebagainya.

Untuk tanda dan denotatumnya Peirce memfokuskan diri pada tiga aspek 
tanda yaitu ikonik, indeksikal dan simbol. Ikonik adalah sesuatu yang melaksanakan fungsi sebagai penanda yang serupa dengan bentuk obyeknya (terlihat pada gambar atau lukisan). Indeks adalah sesuatu yang melaksanakan fungsi sebagai penanda yang mengisyaratkan petandanya, sedangkan simbol adalah penanda yang melaksanakan fungsi sebagai penanda yang oleh kaidah secara kovensi telah lazim digunakan dalam masyarakat.

Secara ringkas analisis semiotiknya Peirce adalah sebagai berikut:

1. Hubungan penalaran dengan jenis penandanya.

a. Qualisigns : Penanda yang bertalian dengan kualitas

b. Sinsign : Penanda yang bertalian dengan kenyataan

c. Legisign : Penanda yang bertalian dengan kaidah

d. Hubungan kenyataan dengan jenis dasarnya

2. Icon : sesuatu yang melaksanakan fungsi sebagai penanda yang serupa dengan bentuk objeknya

a. Index : sesuatu yang melaksanakan funsi sebagai penanda yang mengisyaratkan penandanya

b. Symbol : Sesuatu yang melaksanakan fungsi sebagai penanda yang oleh kaidah secara konvensi telah lazim di gunakan dalam masayarakat.

3. Hubungan pikiran dengan jenis petandanya

a. Rheme or seme : Penanda yang bertalian dengan mungkin terpahamnya objek

petanda bagi penafsir

b. Dicent or Drcisign or Pheme : penanda yang menampilkan informasi tentang petandanya.

c. Argument : penanda yang petandanya akhir bukan suatu benda tetapi kaidah

Sekurang-kurangnya terdapat sembilan macam semiotik yang kita kenal sekarang (Pateda, dalam Sobur, 2004). Jenis -jenis semiotik ini antara lain semiotik analitik, diskriptif, faunal zoosemiotic, kultural, naratif, natural, normatif, sosial, struktural.

1. Semiotik Analitik, adalah semiotik yang menganalisis sistem tanda

2. Semiotik Deskriptif adalah semiotk yang memeperhatikan sistem tanda yang dapat kita alami sekarang, meskipun ada tanda yang sejak dahulu 
tetap seperti yang disaksiskan sekarang.

3. Semiotik Faunal (Zoo semiotic), adalah semiotik yang khusus memperhatikan sistem tanda yang dihasilkan oleh hewan.

4. Semiotik Kultural, adalah semiotik yang khusus menelaah sistem tanda yang berlaku dalam kebudayaan masyarakat tertentu.

5. Semiotik Naratif adalah semiotik yang menelaah sistem tanda dalam narasi yang berwujud mitos dan cerita lisan (Folkkore)

6. Semiotik Natural, adalah semiotik yang khusus menelaah sistem tanda yang dihasilkan oleh alam.

7. Semiotik Normatif, adalah semiotik yang khusus menelaah sistem tanda yang di buat oleh manusia yang berwujud norma-norma, misalnya rambu-rambu lalu lintas.

8. Semiotik Sosial, adalah semiotik yang khusus menelaah sistem tanda yang dihasilkan oleh manusia yang berupa lambang.

9. Semiotik Struktural, adalah semiotik yang khusus menelaah sistem tanda yang dimanifestasikan melalui struktur bahasa. Semiotik kultural adalah kajian semiotik yang khusus menelaah sistem tanda yang berlaku dalam kebudayaan masyarakat tertentu (Sobur, 2001:101). Jadi kajian berfokus pada sistem tanda yang mewakili pikiran dan perasaan masayarakat sebagai pelaku budaya dan adat istiadat di daerah tertentu.

Hoed (2007:22) menambahkan bahwa dalam melihat kebudayaan sebagai signifying order (urutan tanda) dapat dibedakan empat faktor yang perlu diperhatikan dan berkaitan satu sama lain, yaitu :1. Jenis tanda (ikon, indeks, symbol), 2. Jenis sistem tanda (bahasa, music, gerakan tubuh), 3. Jenis teks (percakapan, lirik lagu, pantun), 4. Jenis konteks/situasi yang mempengaruhi makna tanda (psikologi, sosial, kultural, historis).

Jenis tanda yang dipakai Masyarakat Tapanuli Selatan dalam Mangupa adalah fauna sebagai simbol dimana pemakaiannya dan pemaknaanya bersifat kesepakatan (konvensi). Sedangkan konteks yang mempengaruhi makna tanda tersebut adalah konteks kultural.

\section{MANGUPA}

Upacara Mangupa atau Upah-upah merupakan salah satu upacara adat yang berasal dari Tapanuli Selatan, Sumatera Utara. Upacara Mangupa bertujuan untuk 
mengembalikan tondi ke badan dan memohon berkah dari Tuhan Yang Maha Esa agar selalu selamat, sehat, dan murah rezeki dalam kehidupan. Upaya memanggil tondi ke badan dilakukan dengan cara menghidangkan seperangkat bahan (perangkat pangupa) dan nasehat pangupa (hata pangupa; hata upah-upah) yang disusun secara sistematis dan dilakukan oleh berbagai pihak yang terdiri dari orang tua, raja-raja, dan pihak-pihak adat lainnya.

Ada tiga kondisi di mana upacara Mangupa dapat dilaksanakan, yaitu: (1) hasosorang ni daganak atau kelahiran anak (2) haroan boru atau sering dikenal juga sebagai patobang anak atau perkawinan anak laki-laki, dan (3) marmasuk bagas na imbaru atau memasuki rumah baru (Marakub Marpaung, 1969). Pada saat ini, perkembangan tradisi Mangupa telah disesuaikan dengan kebutuhan masyarakat Tapanuli Selatan sehingga terdapat banyak jenis Mangupa, misalnya Mangupa memasuki rumah baru (marbongkot bagas).

Upacara Mangupa menyajikan perangkat makanan yang diletakkan di atas tampi (niru) dan dialasi oleh bagian ujung daun pisang sebanyak tiga helai. Jenis bahan makanan yang digunakan di dalam Mangupa menentukan besar-kecilnya pesta adat (horja). Makanan yang diolah dari hewan yang disajikan dalam perangkat tersebut menandakan tingkatan besarkecilnya Mangupa yang sedang dilaksanakan. Ada empat jenis bahan dan hewan penting di dalam upacara Mangupa, yaitu:

1. Pira manuk na nihobolan (telur ayam),

2. Manuk (ayam),

3. Hambeng (kambing),

4. Horbo (kerbau), dalam pembicaraan adat dijuluki na bontar (yang putih) (Persadaan Marga Harahap Dohot Boruna, 1993).

Tingkatan Mangupa dalam pesta adat kecil dan mendasar paling sedikit harus memenuhi bahan penting sebutir telur ayam, tingkat kedua harus mengandung ayam, tingkatan ketiga harus mengandung kambing, dan tingkatan tertinggi harus mengandung kerbau. Setiap tingkatan Mangupa yang lebih tinggi harus mengandung unsur bahan dan hewan yang ada dalam tingkatan yang lebih rendah. Misalnya, untuk tingkatan Mangupa tertinggi, yang menggunakan hewan penting berupa kerbau, hidangan pangupa itu juga harus menyajikan kambing, ayam, dan telur. Hewan-hewan penting tersebut tentu saja harus dipadukan dengan berbagai hidangan dan perangkat pangupa yang lain. 
Perangkat Pangupa dengan hewan kerbau adalah sebagai berikut:

1. Alas paling bawah adalah anduri (tampi)

2. Di atas anduri (tampi) ada tiga helai bulung ujung (daun pisang bagian ujung)

3. Di atas bulung ujung ditaruh indahan sibonang manita (nasi putih yang disebut siribu-ribu)

4. Di atas indahan sibonang wanita diletakkan ikan-ikan kecil dari tujuh sungai, biasanya haporas dan incor

5. Di kiri dan kanan, di atas nasi diletakkan masing-masing seekor ikan

6. Di bagian belakang ditaruh parmiakan ni manuk (bagian punggung ayam)

7. Di bagian kiri dan kanan dalam diletakkan paha kerbau

8. Di samping paha kerbau diletakkan dua paha ayam

9. Di depan paha kerbau dan paha ayam diletakkan tiga pira manuk na dihobolan (telur ayam yang masak dan sudah dikupas), yang dibubuhi garam di tengahnya

10. Bagian paling depan adalah kepala kerbau, mata, telinga, bibir dan dagunya

11. Semua pangupa ditutupi dengan sehelai bulung ujung (daun pisang ujung)
12. Paling atas adalah sehelai kain adat, abit godang (selimut adat).

\section{SEMIOTIK FAUNA DALAM}

MANGUPA

Makna semiotik fauna yang digunakan dalam acara mangupa pada perkawinan adat Tapanuli Selatan dapat dilihat pada tabel di bawah ini:

\begin{tabular}{|c|c|c|c|}
\hline $\begin{array}{l}\mathrm{N} \\
\mathrm{o}\end{array}$ & $\begin{array}{l}\text { Jenis } \\
\text { Fauna } \\
\text { (Penan } \\
\text { da) }\end{array}$ & $\begin{array}{l}\text { Dalam } \\
\text { Bahasa } \\
\text { Angkola/T } \\
\text { apsel }\end{array}$ & $\begin{array}{l}\text { Makna } \\
\text { Semiotik } \\
\text { (Petanda) }\end{array}$ \\
\hline 1. & $\begin{array}{l}\text { Telur } \\
\text { ayam }\end{array}$ & Piramanuk & kesetiaan \\
\hline 2. & $\begin{array}{l}\text { Ikan } \\
\text { Gulai }\end{array}$ & Ihan Sayur & $\begin{array}{l}\text { Kesejahtera } \\
\text { an/Kebahag } \\
\text { iaan }\end{array}$ \\
\hline 3. & $\begin{array}{l}\text { Ayam } \\
\text { jantan }\end{array}$ & $\begin{array}{l}\text { Manuk } \\
\text { jantan }\end{array}$ & $\begin{array}{l}\text { Ketegaran } \\
\text { hidup }\end{array}$ \\
\hline 4. & $\begin{array}{l}\text { Kambi } \\
\text { ng } \\
\text { jantan }\end{array}$ & $\begin{array}{l}\text { Hambeng } \\
\text { jantan }\end{array}$ & $\begin{array}{l}\text { Keberkahan } \\
\text { dan } \\
\text { kharisma }\end{array}$ \\
\hline 5. & $\begin{array}{l}\text { Kerbau } \\
\text { jantan } \\
\text { - } \\
\text { hidung } \\
\text { kerbau } \\
\text {-lidah } \\
\text { kerbau } \\
\text {-mata } \\
\text { kerbau } \\
\text {-telinga } \\
\text { kerbau } \\
\text {-kulit } \\
\text { kerbau }\end{array}$ & $\begin{array}{ll}\text { Horbo } & \\
\text { jantan/Na } & \\
\text { Bontar } & \\
\text {-igung } & \text { ni } \\
\text { horbo } & \\
\text {-dila } & \text { ni } \\
\text { horbo } & \\
\text {-mata } & \text { ni } \\
\text { horbo } & \\
\text {-pinggol ni } \\
\text { horbo } \\
\text {-jangat }\end{array}$ & $\begin{array}{l}\text { Keberkahan } \\
\text { /kekuatan } \\
\text {-berhati-hati } \\
\text { dalam hidup } \\
\text {-sopan } \\
\text { santun } \\
\text {-jeli melihat } \\
\text { persoalan } \\
\text { hidup } \\
\text {-tanggap } \\
\text { dalam } \\
\text { bermasyara } \\
\text { kat } \\
\text {-tenggang } \\
\text { rasa }\end{array}$ \\
\hline
\end{tabular}


Setelah diteliti dan ditelaah makna

keseluruhan dari lesikon fauna pada upacara adat Mangupa dalam perkawinan adat

Tapanuli Selatan tersebut adalah berupa

harapan dan doa demi kebahagiaan, kesejahteraan dan kesempurnaan hidup bagi orang yang diupah.

\section{SIMPULAN}

Ekolinguistik, ilmu pengetahuan antardisiplin ilmu, merupakan sebuah payung bagi semua penelitian tentang bahasa (dan bahasa-bahasa) yang dikaitkan sedemikian rupa dengan ekologi. Ada bbeberapa kesimpulan yang dapat ditarik dari kajian ini, antara lain:

1. Dalam kehidupannya, khususnyadalam uapacara adat, masyarakat Tapanuli Selatan banyak menggunakan flora dan fauna sebagai alat untuk mengungkapkan pikiran dan perasaannya. Hal ini ditemukan dalam upacara adat, baik adat perkawinan, adat kelahiran,adat kematian dan sebagainya yang kerap menggunakan flora dan fauna termasuk terminologi flora dan fauna.

2. Makna keseluruhan dari lesikon fauna pada upacara adat Mangupa dalam perkawinan adat Tapanuli Selatan tersebut adalah berupa harapan dan doa demi kebahagiaan, kesejahteraan dan kesempurnaan hidup bagi orang yang diupah.

3. Masyarakat Tapanuli Selatan menyadari betapa pentingnya ekologi dalam mempertahankan kelangsungan hidup, ini dapat dibuktikan dengan pemakaian leksikon fauna dalam upacara adat Mangupa.

\section{DAFTAR PUSTAKA}

De de Saussure, F. 1988. Course in General Linguistics . Yogyakarta: Gajah Mada University Press

Halliday, M A K. 1978. Language as Social Semiotic: The Social Interpretation of Language and Meaning. London: Edward Arnold

Hoed, Benny H. 2002. Strukturalisme, Pragmatik dan Semiotik dalam Kajian Budaya

dalam Indonesia: Tanda yang Retak (Jakarta: Wedatama Widya Sastra.

Mbete, Aron Meko. 2009. Refleksi Ringan tentang Problematika Keetnikan dan Kebahasaan dalam Perspektif Ekolinguistik.

Muhlhausler, Peter and Alwin Fill (Eds.) 2003. The Ecolinguistics Reader. Language, Ecology and Environment. London and New York: Continuum.

Pateda, Mansoer. 2001. Semantik Leksikal. Jakarta: Rineka Cipta

Sobur, Alex. 2004. Analisis Teks Media. Bandung: Remaja Rosdakarya

Vol.3 No.1 Januari - Juni 2018/ 45 
Teew, A. 1984. Khasanah Sastra Indonesia.

Jakarta: Balai Pustaka

L.S. Diapari, 1990. Adat-istiadat perkawinan dalam masyarakat Batak Tapanuli Selatan. Jakarta: Penerbit Penulis.

Bahril Hidayat, 2004. Tema-tema Psikologis dalam tradisi Mangupa pada pasangan pernikahan pemula dalam masyarakat perantau Tapanuli Selatan di Pekanbaru. Yogyakarta: Program Studi Psikologi FPSB UII.

Elfitriana Kaspy Lubis, $1988 . \quad$ Tradisi Mangupa dalam masyarakat suku Batak Angkola Mandailing, skripsi (tidak diterbitkan), Pekanbaru: Fakultas Keguruan dan Ilmu Pendidikan Universitas Riau.

Marpaung Marakub, 1969. Djop ni Roha Pardomuan (Paradaton Tapanuli Selatan) Padang Sidempuan: Pustaka Timur.

Persadaan Marga Harahap Dohot Boruna, 1993. Horja: adat-istiadat Dalihan Na Tolu, musyawarah adat Persadaan Marga Harahap Dohot Anak Boruna di Padang Sidempuan 26-27 Desember 1991, Bandung: PT. Grafiti. 